\title{
Effect of Land Configuration and Weed Management on Mungbean Productivity under Temperate Conditions of Kashmir, India
}

\author{
Fayaz Ahmed Bahar", S.A. Dar, Ajaz A. Lone, S. Ansarul Haq, \\ B.A. Alie, Z.A. Dar, M.A. Bhat and Gul Zaffar \\ Dryland (Karewa) Agriculture Research Station, Budgam, Sher-e-Kashmir University of \\ Agricultural Sciences and Technology Kashmir-190025, India \\ *Corresponding author
}

\section{A B S T R A C T}

A field experiment entitled, "Effect of land configuration and weed management on mungbean productivity under temperate conditions of Kashmir" was conducted during Kharif seasons of 2014 and 2015 under AICRP on MULLaRP. The soil of the experimental field was silty clay in texture, low in organic carbon and medium in nitrogen, phosphorus potassium. The experiment consisted of two treatments of land configuration viz., Flat Bed Method (FBM) and Ridge method (RM) in main plot and four weed management treatments viz., Weedy check, Pendimethalin @ $1.0 \mathrm{~kg}$ a.i/ha PE, Imazethapyr $10 \%$ SL @ 55 g/ha at 15-20 DAS and Pendimethalin 30 EC PE fb imazethapyr $10 \%$ SL @ 55 g/ha at 15-20 DASlaid out in strip plot design (SPD) with three replications. The experimental results revealed that the grain yield of Flat Bed

\section{Keywords}

Mungbean, Grassy weeds, Green gram, Weed management.

Article Info

Accepted:

10 September 2017 Available Online: 10 October 2017
Method $_{(\mathrm{L} 1)}$ was at par with Ridge Method ${ }_{(\mathrm{L} 2)}$ and there was non-significant difference with respect to yield attributing characters. Weed density $\left(\mathrm{No} . / \mathrm{m}^{2}\right)$ and weed dry matter $\left(\mathrm{g} / \mathrm{m}^{2}\right)$ also exhibited non-significant difference at 30 and 60 days after sowing (DAS) of crop. Among weed management practices, weedy check recorded the lowest grain yield of $552 \mathrm{~kg} / \mathrm{ha}$ and showed significant difference when compared with rest of the treatments, whereas highest grain yield of $818.75 \mathrm{~kg} / \mathrm{ha}$ was recorded with pendimethalin 30 EC @ 1.0 kg/ha-PE followed by imazethapyr $10 \%$ SL @ $55 \mathrm{~g} / \mathrm{ha}$ at 15-20 DAS, imazethapyr $10 \%$ SL @ 55 g/ha at 15-20 DAS and pendimethalin 30 EC @ 0.75/1.0 kg a.i /ha PE in decreasing order. Pendimethalin 30 EC @ $1.0 \mathrm{~kg} / \mathrm{ha}-\mathrm{PE} \mathrm{fb}$ Imazethapyr $10 \%$ SL @ $55 \mathrm{~g} / \mathrm{ha}$ at 15-20 DAS, imazethapyr $10 \% \mathrm{SL} @ 55 \mathrm{~g} / \mathrm{ha}$ at 15-20 DAS and Pendimethalin 30 EC @ 0.75/1.0 kg a.i /ha PE recorded $48.04 \%$, $33.92 \%$ and $18.62 \%$ increase in grain yield respectively than weedy check. The major weeds identified in the experimental field were Cynodon dactylon, Sorghum halepense, Conyza spp., Matricaria spp., Poa spp. among Grassy weeds; Convolvulus arvensis, Amaranthus viridis, Chenopodium album among broadleaved weeds and Cyperus rotundus among sedges. Highest monetary returns and B: C ratio (Rs. 68500/ha and 1.96) was recorded in pendimethalin 30 EC @ 0.75/1.0 kg a.i. /ha PE fb imazethapyr $10 \%$ SL @ 55 g/ha at 15-20 DAS (W4) and lowest monetary returns and B: C ratio (Rs. 46160/ha and 1.07) was recorded in weedy check. Among weed management practices, uncontrolled weedy check resulted in 32.58 per cent reduction in grain yield of mungbean. 


\section{Introduction}

Mung bean (Vigna radiata), alternatively known as the moong bean, green gram, belongs to legume family. It is one of the important pulse crops in $\mathrm{J} \& \mathrm{~K}$ and plays a major role in augmenting the income of small and marginal farmers of Valley. Mungbean contains 25 percent of highly digestible protein and is consumed both as whole grain as well as dal. It is a soil building crop which fixes atmospheric nitrogen through symbiotic action and can also be used as green manure crop adding $35 \mathrm{~kg} \mathrm{~N} \mathrm{ha}^{-1}$. Mungbean has proven to be invaluable in crop rotation helping in improving soil texture and fertility and conserve natural resources providing long term sustainability in agricultural productivity. It can utilize limited soil moisture and nutrients more efficiently than cereal crops and for that reason farmers have chosen them to grow under highly adverse conditions.

Among the various constraints responsible for low yield of mungbean like scarcity of water, delayed sowing, inadequate seed replacement rate, lack of transfer of technology, inadequate weed management etc. Method of sowing and weed management holds an utmost importance as weeds harbor insectpests and act as an alternate and secondary source for the dispersal and persistence of diseases and insect pest complex. Keeping in view the above facts, a field experiment entitled, "Effect of land configuration and weed management on mungbean productivity" was conducted during Kharif season of 2014 and 2015 under AICRP on MULLaRP.

\section{Materials and Methods}

The field experiment was conducted at Dryland (Karewa) Agriculture Research Station (DARS) Budgam, Sher-e-Kashmir University of Agricultural Sciences and
Technology Kashmir. The soil of the experimental field was silty clay in texture, low in organic carbon and medium in nitrogen, phosphorus and potassium. Fertilizer NPK @ 30-60-30 kg/ha was applied as a common dose to all the treatments. Sowing of mungbean 'Shalimar mung-2' was done on June 15 during both the years. The experiment consisted of two land configuration treatments viz., Flat Bed Method $\left(\mathrm{L}_{1}\right)$ and Ridge method $\left(\mathrm{L}_{2}\right)$ in main plot and four weed management treatments viz, weedy check $\left(\mathrm{W}_{1}\right)$, Pendimethalin @ $1.0 \mathrm{~kg}$ a.i/ha PE $\left(\mathrm{W}_{2}\right)$, imazethapyr $10 \%$ SL @ 55 g/ha at $15-20$ DAS $\left(\mathrm{W}_{3}\right)$ and pendimethalin $30 \mathrm{EC}$ PE fb imazethapyr $10 \%$ SL @ 55 g/ha at 15-20 DAS $\left(\mathrm{W}_{4}\right)$ laid out in strip plot design (SPD) with three replications. Weed samples were collected by placing a quadrate $(0.50 \mathrm{~m} \times 0.50$ $\mathrm{m})$ randomly at two places in each plot. The observations taken at 30,60 DAS and crop harvest were compared and analysed. Weed control efficiency (WCE) was calculated according to the standard formula. The economic analyses were carried out by computing the market price of inputs and outputs during both the experimental years (Fig. 1).

\section{Results and Discussion}

The major weed species identified in the experimental field were broad leaved weeds like; Convolvulus arvensis, Amaranthus viridis, Chenopodium album, Physallis minima and Datura stramonium grasses like; Cynodon dactylon, Sorghum halepense, Conyza spp., Matricaria spp., Poa spp. and Cyperus rotundus among sedges (Fig. 2). Similar observations were also observed by Tamang et al., (2015).

\section{Effect of different treatments on weed dynamics}

Experimental results revealed that crop establishment methods viz., furrow bed 
method (L1) and ridge method (L2) have nonsignificant effect on the total weed density (TWD), total weed dry matter accumulation (TWDMA) and relative composition (\%) of weeds at 60 days after sowing (DAS). Highest total weed density (TWD), total weed dry matter accumulation (TWDMA) and relative composition (\%) of weeds was recorded in the uncontrolled weedy check which was significantly higher than pendimethalin $30 \mathrm{EC}$ @ $1.0 \mathrm{~kg} / \mathrm{ha}-\mathrm{PE}$, imazethapyr $10 \%$ SL @ 55 $\mathrm{g} / \mathrm{ha}$ at 15-20 DAS and pendimethalin $30 \mathrm{EC}$ @ $1.0 \mathrm{~kg}$ a.i /ha PE followed by imazethapyr $10 \%$ SL @ 55 g/ha at 15-20 DAS respectively. Pre-emergence application of pendimethalin $30 \mathrm{EC} @ 0.75 / 1.0 \mathrm{~kg}$ a.i /ha significantly reduced the total weed density (TWD), total weed dry matter accumulation (TWDMA) and relative composition (\%) of weeds at 60 DAS.

Post-emergence application of imazethapyr $10 \%$ SL @ $55 \mathrm{~g} / \mathrm{ha}$ at 15-20 DAS and preemergence application of pendimethalin 30 EC @ $1.0 \mathrm{~kg}$ a.i /ha followed by imazethapyr $10 \%$ SL @ 55 g/ha at 15-20 DAS were effective in controlling weed population and weed dry matter accumulation and were statistically at par with respect to relative weed composition of broadleaved weeds, grassy weeds and sedges like Cyperus rotundus (Table 1 ).

The highest total weed density of 25.69 and 45.73 No. $/ \mathrm{m}^{2}$ and dry matter accumulation of 34.32 and $63.66 \mathrm{~g} / \mathrm{m}^{2}$ were recorded in weedy check, whereas lowest total weed density of 5.42 and $9.0 \quad$ No. $/ \mathrm{m}^{2}$ and dry matter accumulation of 6.50 and $11.40 \mathrm{~g} / \mathrm{m}^{2}$ at 30 and 60 DAS were recorded in imazethapyr $10 \%$ SL @ 55 g/ha at 15-20 DAS and pendimethalin $30 \mathrm{EC} @ 1.0 \mathrm{~kg}$ a.i /ha PE followed by imazethapyr $10 \%$ SL @ $55 \mathrm{~g} / \mathrm{ha}$ at 15-20 DAS respectively. Higher weed control efficiency (WCE) and long lasting effects of imazethapyr in reducing weed dry matter might be due to broad spectrum activity of herbicides particularly on established plants of both narrow and broadleaved weeds and its greater efficiency to retard cell division of meristems as a result of which weed died rapidly. Similar results were reported by Lhungdim et al., 2014. Superiority of Pendimethalin 30 EC @ 1.0 kg a.i /ha PE followed by imazethapyr $10 \% \mathrm{SL}$ @ $55 \mathrm{~g} / \mathrm{ha}$ at $15-20$ DAS was attributed to weed seed damaged by pendimethalin as preemergence and suppression of emerging weeds by imazethapyr (Chauhan et al.,).

The large dry biomass production in weaker treatments were due to ineffective suppression of weeds at their initial and active growth stages leading to maturity and fair dry matter accumulation.

Highest weed control efficiency (WCE) of $83.6 \%$ and $81.0 \%$ was recorded in the preemergence application of pendimethalin 30 EC @ $1.0 \mathrm{~kg}$ a.i /ha fb imazethapyr $10 \% \mathrm{SL}$ @ $55 \mathrm{~g} / \mathrm{ha}$ at 15-20 DAS and imazethapyr 10 $\%$ SL @ 55 g/ha at 15-20 DAS respectively. Similarly Ram et al., 2011 reported maximum WCE of $86.6 \%$ in pea $78.2 \%$ in lentil (Lhungdim et al., 2014). However imazethapyr $10 \%$ SL @ 55 g/ha at 15-20 DAS and pendimethalin 30 EC @ 1.0 kg a.i /ha fb imazethapyr $10 \%$ SL @ 55 g/ha at 1520 DAS were at par on WCE.

No interaction was observed between the crop established methods and weed management practices.

\section{Effect of different treatments on crop growth dynamics}

A perusal on pooled data (Table 2) showed that there was non-significant difference between different crop establishment methods with respect to growth parameters and yield attributing characters of mungbean. 
Table.1 Effect of land configuration and weed management on mungbean productivity (pooled data of two years)

\begin{tabular}{|c|c|c|c|c|c|c|c|c|}
\hline Treatment & $\begin{array}{l}\text { No. of pry. } \\
\text { branches }\end{array}$ & $\begin{array}{l}\text { No. of sec. } \\
\text { branches }\end{array}$ & $\begin{array}{l}\text { Nodule count } \\
\text { /pt.at } 60 \text { DAS }\end{array}$ & $\begin{array}{l}\text { Plant height } \\
(\mathrm{cm})\end{array}$ & $\begin{array}{l}\text { Pod length } \\
(\mathrm{cm})\end{array}$ & $\begin{array}{l}\text { No. of } \\
\text { pods/pt. }\end{array}$ & $\begin{array}{l}\text { No. of } \\
\text { seeds/pod }\end{array}$ & $\begin{array}{l}\text { Grain yield } \\
\text { (kg/ha) }\end{array}$ \\
\hline \multicolumn{9}{|l|}{ A. Land configuration } \\
\hline$\left(\mathrm{L}_{1}\right) * \mathrm{FBM}$ & 2.1 & 5.2 & 37 & 121.75 & 9.25 & 30.25 & 10.31 & 697.12 \\
\hline$\left(\mathrm{L}_{2}\right) * * \mathrm{RM}$ & 2.1 & 5.3 & 40 & 118.18 & 9.19 & 30.87 & 10.00 & 687.18 \\
\hline C. V & 0.002 & 0.007 & - & 3.70 & 3.64 & 7.10 & 5.22 & 4.81 \\
\hline C.D. $(5 \%)$ & NS & NS & - & $\mathrm{NS}$ & $\mathrm{NS}$ & $\mathrm{NS}$ & $\mathrm{NS}$ & 7.012 \\
\hline \multicolumn{9}{|l|}{ B. Weed Management } \\
\hline$\left(\mathrm{W}_{1}\right)$ Weedy check & 1.0 & 3.6 & 41 & 115.00 & 7.97 & 25.00 & 8.25 & 552.0 \\
\hline$\left(\mathrm{W}_{2}\right)$ Pendi. @ $1.0 \mathrm{~kg} \mathrm{a.i/ha} \mathrm{PE}$ & 1.6 & 4.6 & 31 & 115.50 & 8.62 & 30.62 & 9.75 & 659.25 \\
\hline$\left(\mathrm{W}_{3}\right)$ Imazethapyr $10 \% @ 55 \mathrm{~g} / \mathrm{ha}$ at $15-20 \mathrm{DAS}$ & 1.7 & 4.8 & 27 & 125.25 & 9.21 & 32.12 & 10.62 & 738.62 \\
\hline$\left(\mathrm{W}_{4}\right)$ Pendi. PE fb Imazethapyr 15-20 DAS & 2.1 & 5.3 & 21 & 124.12 & 11.07 & 34.50 & 12.00 & 818.75 \\
\hline C. V & 0.986 & 0.987 & - & 4.75 & 3.81 & 5.99 & 5.71 & 5.91 \\
\hline C.D. $(5 \%)$ & 0.3 & 0.29 & - & $\mathrm{NS}$ & 0.52 & 1.62 & 1.07 & 12.95 \\
\hline
\end{tabular}

*FBM: Furrow Bed Method; **RM: Ridge method

Table.2 Effect of land configuration and weed management on weed dynamics and economics of mungbean

(Pooled data of two years)

\begin{tabular}{|c|c|c|c|c|c|c|c|c|c|c|c|}
\hline \multirow[t]{2}{*}{ Treatment } & \multicolumn{2}{|c|}{ Weed density $\left(\mathrm{No} . / \mathrm{m}^{2}\right)$} & \multicolumn{2}{|c|}{ Weed dry matter $\left(\mathrm{g} / \mathrm{m}^{2}\right)$} & \multicolumn{3}{|c|}{$\begin{array}{l}\text { Relative composition (\%) at } 60 \\
\text { DAS }\end{array}$} & \multirow[t]{2}{*}{$\begin{array}{l}\text { WCE } \\
(\%)\end{array}$} & \multirow{2}{*}{$\begin{array}{c}\text { Cost of } \\
\text { cultivation } \\
\text { (Rs./ha) }\end{array}$} & \multirow{2}{*}{$\begin{array}{c}\text { Net } \\
\text { returns } \\
\text { (Rs./ha) }\end{array}$} & \multirow[t]{2}{*}{$\begin{array}{l}B: C \\
\text { ratio }\end{array}$} \\
\hline & 30 DAS & 60 DAS & 30 DAS & 60 DAS & BLWs & Grasses & Sedges & & & & \\
\hline \multicolumn{12}{|l|}{ A. Land configuration } \\
\hline$\left(\mathrm{L}_{1}\right) * \mathrm{FBM}$ & 12.31 & 15.56 & 15.31 & 16.75 & 12.31 & 15.56 & 15.31 & - & 34000 & 58770 & 1.73 \\
\hline$\left(\mathrm{L}_{2}\right) * * \mathrm{RM}$ & 12.31 & 15.12 & 14.00 & 15.56 & 12.31 & 15.12 & 14.00 & - & 34000 & 57974 & 1.71 \\
\hline C. V & 16.07 & 37.46 & 6.93 & 12.30 & 16.07 & 37.46 & 6.93 & - & - & - & - \\
\hline C.D. $(5 \%)$ & NS & NS & 0.82 & NS & NS & NS & 0.82 & - & - & - & - \\
\hline \multicolumn{12}{|l|}{ B. Weed Management } \\
\hline$\left(\mathrm{W}_{1}\right)$ Weedy check & 26.62 & 34.50 & 35.75 & 41.62 & 26.62 & 34.50 & 35.75 & 0 & 43000 & 46160 & 1.07 \\
\hline$\left(\mathrm{W}_{2}\right)$ Pendi. @ $1.0 \mathrm{~kg}$ a.i /ha PE & 14.12 & 19.00 & 12.75 & 13.75 & 14.12 & 19.00 & 12.75 & 51.82 & 34400 & 55240 & 1.61 \\
\hline $\begin{array}{l}\left(\mathrm{W}_{3}\right) \text { Imazeth. } 10 \% \text { @ } 55 \mathrm{~g} / \mathrm{ha} \text { at } \\
15-20 \text { DAS }\end{array}$ & 5.62 & 5.00 & 6.25 & 6.37 & 5.62 & 5.00 & 6.25 & 81.0 & 34600 & 62090 & 1.79 \\
\hline $\begin{array}{l}\left(\mathrm{W}_{4}\right) \text { Pendi. PE fb Imazethapyr } \\
\text { 15-20 DAS }\end{array}$ & 2.87 & 2.87 & 3.87 & 2.87 & 2.87 & 2.87 & 3.87 & 83.60 & 35000 & 68500 & 1.96 \\
\hline C. V & 16.63 & 24.36 & 17.36 & 21.32 & 16.63 & 24.36 & 17.36 & - & - & - & - \\
\hline C.D.(5\%) & 4.76 & 4.77 & 2.93 & 2.39 & 4.76 & 4.77 & 2.93 & - & - & - & - \\
\hline
\end{tabular}

*FBM: Furrow Bed Method; **RM: Ridge method 
Fig.1 Comparison between two methods of sowing

Ridge Bed Method (RBM)

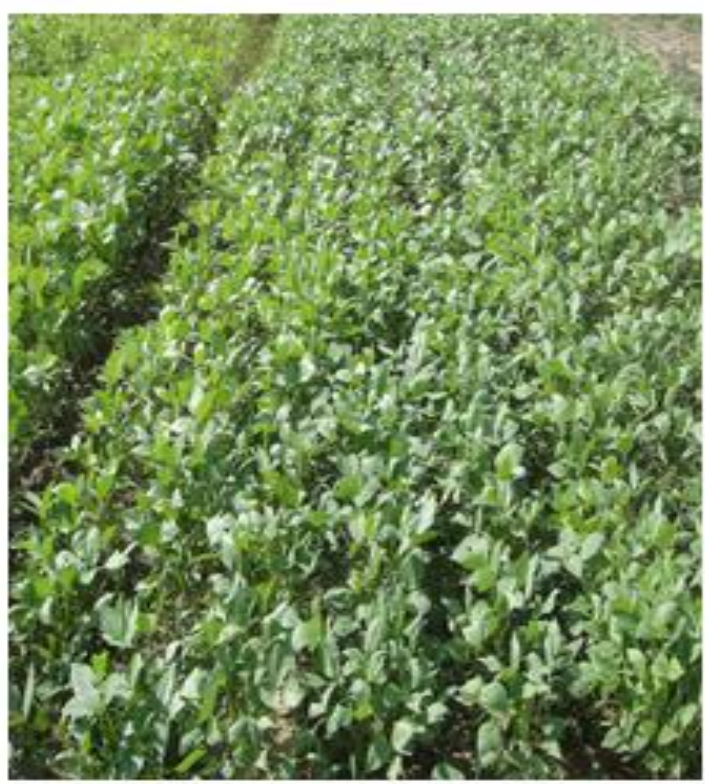

Flat Bed method (FBM)

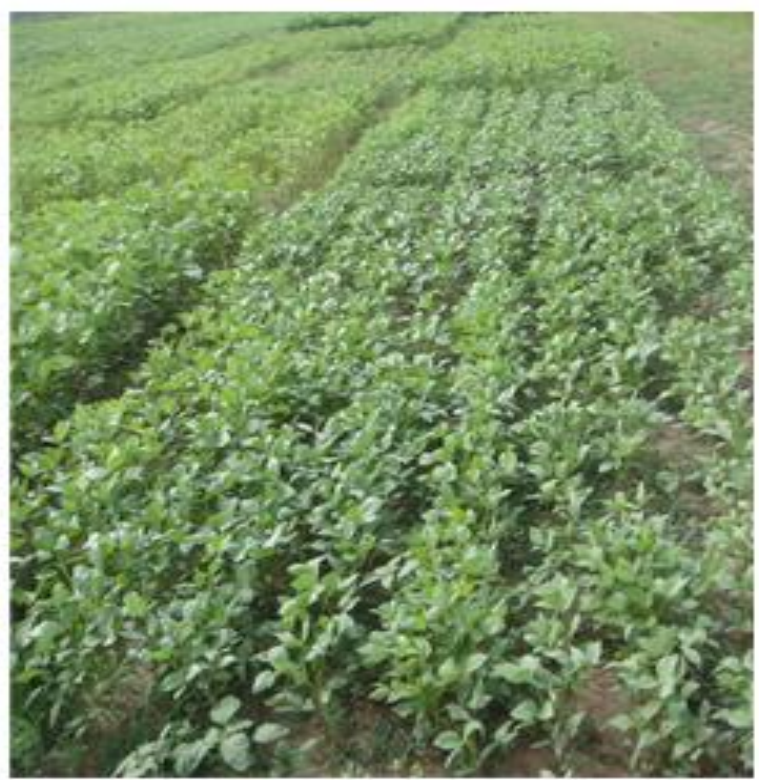

Fig.2 Some major weeds of the experimental field

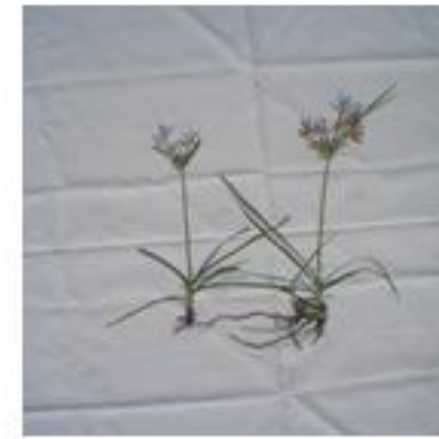

Cyperus iria

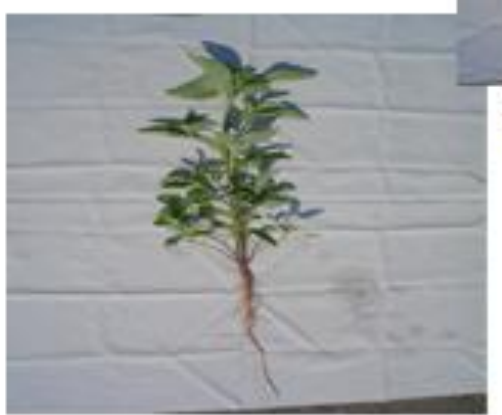

Amaranthus viridis

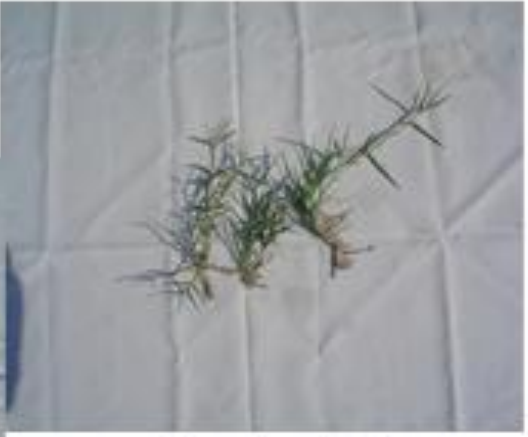

Cynodon dactylon

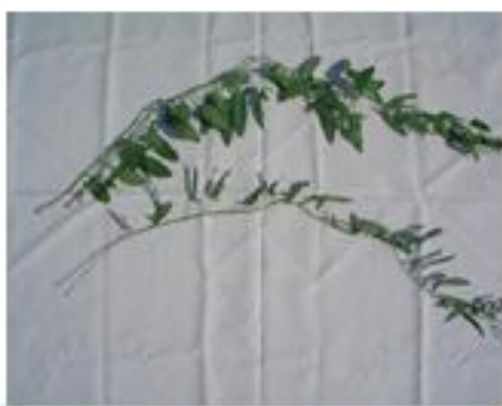

Convolvulus arvensis 
Fig.3 Nodule count in the experimental field

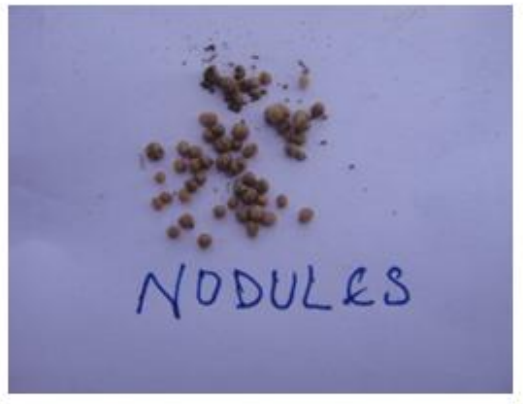

Pre-emergence application of pendimethalin 30 EC @ $1.0 \mathrm{~kg}$ a.i /ha fb imazethapyr $10 \%$ SL @ 55 g/ha at 15-20 DAS recorded significantly higher number of primary and secondary branches per plant than weedy check but was statistically at par with imazethapyr $10 \%$ SL @ 55 g/ha at 15-20 DAS and pre-emergence application of pendimethalin 30 EC @ $1.0 \mathrm{~kg}$ a.i /ha respectively. Tallest plants were recorded with post emergence application of imazethapyr $10 \%$ SL @ $55 \mathrm{~g} / \mathrm{ha}$ at 15-20 DAS and pre-emergence application of pendimethalin 30 EC @ $1.0 \mathrm{~kg}$ a.i /ha fb imazethapyr 10\% SL @ 55 g/ha at 15-20 DAS. This may be attributed to better crop growth environment along with less crop weed competition in these treatments than weedy check (Table 1).

Nodule counts (Table 2) recorded at 60 DAS indicated that nodule formation was more favoured with the nonherbicide plots than sole chemical and chemical-chemical combination treated plots. Highest nodules were recorded under ridge method (L2) than furrow bed method (L1) among the land configuration treatments and were similar. Among the weed management methods, weedy check recorded the highest nodule count (41) than rest of the treatments followed by pendimethalin $30 \mathrm{EC}$ @ $1.0 \mathrm{~kg}$ a.i /ha (31), post emergence application of imazethapyr $10 \%$ SL @ 55 g/ha at 15-20 DAS (27) and pre-emergence

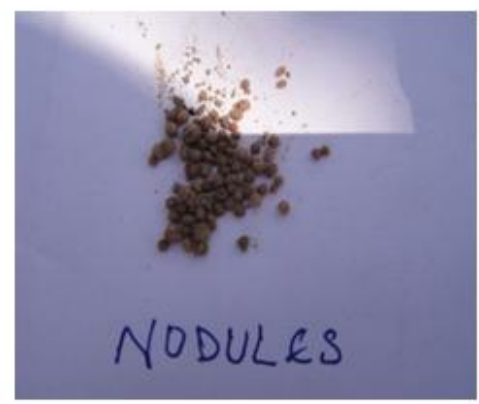

application of pendimethalin $30 \mathrm{EC} @ 1.0 \mathrm{~kg}$ a.i /ha fb imazethapyr $10 \%$ SL @ 55 g/ha at 15-20 DAS (21) in decreasing order. Weak nodulation was more pronounced in chemicalchemical combination and sole chemical as compared to nonchemical method (Fig. 3).

Thus, pendimethalin, imazethapyr and pendimethalin $\mathrm{fb}$ imazethapyr treated plots registered least nodule as the herbicide is believed to interfere in the rhizobium plant relationship. Strong nodulation either in chemical free treatment could be due to direct or indirect effect of herbicides to the symbiotic association of mung and rhizobium thereby inhibiting nitrogenase activity (Lhungdim et al., 2014).

In pulse crops number of pods $/ \mathrm{m}^{2}$ is the most important determinant of grain or seed yield. The number of pods $/ \mathrm{m} 2$, which normally gives a more reliable or accurate picture and contributing most in determining the yield, is presented here as main yield component (Table 2). The number of pods/plant ranged from 25.00 in uncontrolled weedy check to 34.50 in pendimethalin 30 EC @ $1.0 \mathrm{~kg}$ a.i /ha fb imazethapyr $10 \%$ SL @ $55 \mathrm{~g} / \mathrm{ha}$ at 1520 DAS. Treatments imazethapyr $10 \%$ SL @ $55 \mathrm{~g} / \mathrm{ha}$ at $15-20$ DAS and pendimethalin 30 EC @ $1.0 \mathrm{~kg}$ a.i /ha were, however, statistically at par with each other. The results confirm the findings of Kumar et al., 2004 and Veeraputhiran 2009. 
Number of seeds/pod is another important yield component of green gram crop. The weed management treatments had significant effect on number of seeds/pod.

The number of seeds/pod varied from 8.25 in weedy check to 12.0 in pendimethalin $30 \mathrm{EC}$ @ $1.0 \mathrm{~kg}$ a.i /ha fb imazethapyr $10 \%$ SL @ $55 \mathrm{~g} / \mathrm{ha}$ at 15-20 DAS treatment, however, treatments imazethapyr $10 \%$ SL @ 55 g/ha at 15-20 DAS and pendimethalin30 EC @1.0 $\mathrm{kg}$ a.i /ha were statistically at par with each other (Table 2). Pod length also varied from $7.97 \mathrm{~cm}$ to $11.07 \mathrm{~cm}$ among the different weed management practices.

\section{Effect of different treatments on grain yield and economics}

Highest grain yield of $697.12 \mathrm{Kg} / \mathrm{ha}$ was recorded with FBM which was at par with RM. Seed yield of the crop was distinctly influenced by the weed management treatments. Among the different weed management practices, W4 (pendimethalin 30 EC @ 0.75/1.0 kg a.i. /ha PE fb imazethapyr $10 \%$ SL @ 55 g/ha at 15-20 DAS) recorded the highest grain yield of $818.75 \mathrm{Kg} / \mathrm{ha}$ which was significantly higher than rest of the weed management practices. Uncontrolled weedy check (W1) recorded the lowest grain yield of $552 \mathrm{Kg} / \mathrm{ha}$ followed by $\mathrm{W} 2$ and $\mathrm{W} 3$ in increasing order. The reduction in yield under the control treatment (i.e. in W1) may be attributed to more crop weed competition and reduction of yield attributing characters. The average seed yield obtained was significantly more with weed management practices. Crop performance was not good in the control treatment, thus, the yield per hectare was significantly lower than that obtained in other treatments (Table 2). Uncontrolled weed check caused $32.58 \%$ reduction in grain yield of mungbean. The results are in conformity with the findings reported by Malik et al., (2005), and Veeraputhiran (2009).
Both the land configuration treatments viz; FBM and RM recorded almost the same monetary returns (Rs. 58770/ha and Rs. 57974/ha) and B: C ratio (1.73 and 1.71). Among the weed management practices, application of herbicides alone or in combinations recorded higher monetary returns and $\mathrm{B}$ : $\mathrm{C}$ ratio over weedy check (Table 2). Pendimethalin 30 EC @ 0.75/1.0 kg a.i. /ha PE fb imazethapyr $10 \%$ SL @ 55 $\mathrm{g} /$ ha at 15-20 DAS (W4) recorded the maximum monetary returns and $\mathrm{B}$ : $\mathrm{C}$ ratio (Rs. 68500/ha and 1.96) and was followed by imazethapyr 10\%@ @0/55 g/ha at 15-20 DAS (Rs. 62090/ha and 1.79) and pendimethalin@0.75/1.0 kg a.i /ha PE (Rs. 55240/ha and 1.61) in decreasing order. This may be attributed to low crop weed competition, low weed density and dry matter accumulation with higher grain yield than uncontrolled weedy check. The weedy check treatment (W1) had the lowest monetary returns and B: C ratio (Rs. 46160/ha and 1.07) due to heavy weed infestation and poor yield. The tremendous weed infestation in weedy check treatment drastically reduced the yield of the crop. Tamang et al., (2015) also reported the similar results.

Based on the experimental findings it can be concluded that Flatbed method (L1) was at par with ridge method (L2) and there was nonsignificant difference with respect to yield and yield attributing characters. Among weed management practices, highest grain yield was recorded with pendimethalin 30 EC @ 1.0 $\mathrm{kg} / \mathrm{ha}-\mathrm{PE}$ fb imazethapyr $10 \% \mathrm{SL} @ 55 \mathrm{~g} / \mathrm{ha}$ at 15-20 DAS along with maximum monetary returns and $\mathrm{B}$ : $\mathrm{C}$ ratio and can be recommended for weed management in mungbean under temperate conditions.

\section{References}

Chauhan, P. R., Jha, A. K., Sharma, J. K. and Jha, G. 2012. Efficacy of chlorimuron 
ethyl in transplanted rice. Extended summaries of the $3^{\text {rd }}$ Intl. Agronomy Congress. Nov. 26 - 30. Vol. 3, Pp 918 -919 .

Kaur, G., Brar, H. S. and Singh, G. 2009. Effect of weed management on weeds, growth and yield of summer mungbean (Vigna radiata (L.) R. Wilczek). Indian Journal of Weed Science. 41 (3 \& 4): $228-231$.

Kumar, A., Tewari, A.N. 2004. Crop weed competition studies on summer sown black gram (Vigna mungo L.). Indian journal of Weed Science 36: 76-78.

Lhungdim, J., Singh, Y., Singh, O. N. and Chongtham, S. K. 2014. Efficiency of different weed control methods on yield and economics of rainfed lentil (Lens culinaris Medikus). Journal of Food Legumes 27(1): 32-36.

Malik, R.S., Yadav A, Malik RK, Singh S
2005. Performance of weed control treatments in mung bean under different sowing methods. Indian Journal of weed science 37: 273-274.

Ram Baldev, Punia S.S., Meena D.S., and Terarwal J.P. 2011. Bio-efficacy of post emergence herbicides to manage weeds in field pea. Journal of Food Legumes 24: 254-257.

Tamang, D., Nath, R. and Sengupta, K. 2015. Effect of Herbicide Application on Weed Management in Green Gram [Vigna radiata (L.) Wilczek]. Advances in Crop Science and Technology. 3 (2): 161-163.

Veeraputhiran, R., 2009. Effect of mechanical weeding on weed infestation and yield of irrigated black gram and green gram. Indian journal of Weed Science, 41: 7577.

\section{How to cite this article:}

Fayaz Ahmed Bahar, S.A. Dar, Ajaz A. Lone, S. Ansarul Haq, B.A. Alie, Z.A. Dar, M.A. Bhat and Gul Zaffar. 2017. Effect of Land Configuration and Weed Management on Mungbean Productivity under Temperate Conditions of Kashmir, India. Int.J.Curr.Microbiol.App.Sci. 6(10): 863-870. doi: https://doi.org/10.20546/ijcmas.2017.610.103 